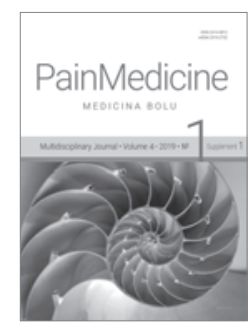

DOI: $10.31636 /$ pmjua.t2.16

\title{
Оцінка аналгетичної ефективності блокади квадратного м'яза попереку (Quadratus Lumborum block), виконаного під контролем ультразвуку у дітей після апендектомії
}

\author{
Залецький Б. В., Дмитрієв Д. В., Глазов Є. О., Вітковський В. В. \\ Вінницький національний медичний університет ім. М. І. Пирогова, Вінниця, Україна
}

Вступ. За даними літератури, для знеболення в періопераційному періоді використовують регіональні методи знеболення. Аналгетичну ефективність блокад передньої черевної стінки в педіатричній практиці вивчено недостатньо. Метою дослідження було оцінити аналгетичну дію блокади квадратного м'яза попереку (QLB) у педіатричних пацієнтів після апендектомії.

Методи. Дане дослідження було виконане на базі Вінницького національного медичного університету, м. Вінниця, Україна, з грудня 2018 по лютий 2019 року. Рандомізовані до групи Q (група з виконанням блокади QLB) та групи C (контрольна). Після отримання загальної анестезії групі Q виконано блокаду квадратного м'яза попереку (QL) з використанням 0,3 мл/кг 0,25\% бупівакаїну 3 одної сторони, та група С отримала контрольний блок 3 використанням 0,3 мл/кг 0,9\% хлориду натрію. Протягом перших 24 годин після операції біль у пацієнтів оцінювали за допомогою візуальної аналогової шкали (VAS) у спокої і при кашлі. Післяопераційний пацієнт контролював споживання морфіну, аналгезію, показники VAS та побічні ефекти.

Результати. Із 22 пацієнтів, у пацієнтів групи $\mathrm{Q}(\mathrm{n}=10)$ мала значно нижчі показники VAS-болю, ніж група C ( $\mathrm{n}=12)$ як у спокої, так і під час кашлю. Загальний рівень споживання морфіну був нижчим $(5,3 \pm 2,2)$ проти $12,4 \pm 3,4$ мг, р < 0,001) протягом 24 годин після операції.

Висновок. Як частина мультимодального знеболення після оперативних втручань 3 приводу апендициту, показники споживання морфіну та VAS-балів були значно нижчими серед тих, хто отримував 0,3 мл/кг 0,25\% розчину бупівакаїну, який вводили для блокади квадратного м'яза попереку, порівняно з групою контролю.

\section{Література}

1. Kadam V. R. Ultrasound-guided quadratus lumborum block as a postoperative analgesic technique for laparotomy / V. R. Kadam // Journal of Anaesthesiology Clinical Pharmacology. - 2013. - № 29 (4). P. 550-552. 